Ann. Biol. anim. Bioch. Biophys., I976, 16 (г), тог-го6.

\title{
CHANGES IN SOME PONDERAL AND METABOLIC PARAMETERS IN CHICKS AGED ONE TO THREE MONTHS
}

\author{
Centrul de cercetari biologice, \\ Strada Republicii 48, \\ 3400 Cluj (Roumanie)
}

C. WITTENBERGER, J. MADAR, Rodica GIURGEA, Delia SUTEU, Livia CHIS, D. COPREAN and Ana ILONCA with the technical aid of I. ILyÉs, Magda Koszta and Maria PoP

\begin{abstract}
SUMMARY
Body and organ weights, water content of some organs, some hematological parameters, glycogen and lipid contents of the liver, ascorbic acid content of the adrenals, and SDH, GPT and GOT activities of hepatic tissue were determined in chicks aged 5 to I I weeks. Sharp modifications were found, most of them being concentrated about the age of 7 weeks. This age is characterized by maximal hematocrit value and a very low hemoglobin concentration of the blood, by maximal concentrations of plasma calcium and phosphate, by minimal levels of liver lipids, adrenal ascorbate, blood glucose, and hepatic GOT activity. This " critical period "of the ontogenesis of the domestic fowl seems to imply a switch over of the main energetic role from fats to carbohydrates.
\end{abstract}

\section{INTRODUCTION}

Despite of a large number of papers on the ontogenesis of the domestic fowl, the physiological and biochemical development of young fowl older than one month is but poorly investigated. Many functional parameters reach the values of the adult fowl before 30 days of age. So are various tissular enzyme activities and their hormonal regulation (KuzNetsova and PerTSeVA, I974 $a, b$; LEIBson et al., I974; PERTSEVA et al., I974), the blood picture (FREEMAN, I97I $a$ ), the body temperature and the thermoregulating ability (FREEMAN, I97 I $b$ ), the general functioning of the hypophyseal-adrenal axis (NvOTA, I973), and so on. There are however metabolical, regulational and behavioural functions which are not yet matured at this age.

In the experiments reported here we followed the evolution of some ponderal and metabolic parameters during the age period from 5 to II weeks. 


\section{MATERIAL AND METHODS}

The experiments were performed on tetralinear hybrid Studler-Cornish chicks. These were purchased from a commercial hatchery during the first day of posteclosional life, and were then reared in our laboratory, being fed with concentrated fodder appropriate to their age.

Groups of 20 chickens each were sacrificed by decapitation at 5, 7, 9, and I I weaks of life.

Blood plasma calcium was determined by an oxalate-permanganate titration method. For total phosphorus, the plasma was minerelized with sulphuric acid, and photocolorimetric determination performed with ammonium molybdate and ferrous sulphate. Total cholesterol content of the blood was measured by means of ferric chloride reaction. KLImov's method (Asatiani, I957) was used for determination of the ascorbic acid content of the adrenals. Hepatic aminotransferase activities (GoT and GPT) were measured by the technique of REITMANN and FRANKEL (FAUVERT, I96I-1962), and succinate dehydrogenase activity (SDH) by a classical Warburg procedure. Blood glucose was assayd following NeLson's modification of the Somogyi method (NELSON, 1944), and liver glycogen following Montgomery (I957). All other determinations were made by standard clinical procedures.

\section{RESULTS AND DISCUSSION}

According to literature data, there are several functional modifications occurring in the organism of the domestic fowl during the age period investigated in this work. The central nervous system reaches its functional maturity : the RNA content of the brain reaches the adult value by 5 weeks, the electroencephalogram gains its final form by 8 weeks (BoLTON, I97I). The glycogen phosphorylase activity of the muscle tissue increases until about 7 weeks (PERTSEVA et al., r974). The rate of metabolism, after a maximum by 4 weeks, is decreasing (STURKIE, I965). The milt attains its maximal relative weight between 6 and ro weeks (PAYNE, I97I). An immunological maturation takes place : the gamma-globuline concentration of the blood serum is increasing until about I3 weeks (TsinovyJ, I967). Summing up, one can say that, in many respects, the fowl is mature by $80-90$ days. Only in sexual functions maturity is not reached until I8-20 weeks (GILBERT, I97I ; LAKE, I97I).

\section{TABLE I}

Variation of body and organ weights with the age

(Values are given as means, 土 standard errors; in parentheses, number of individuals)

\begin{tabular}{|c|c|c|c|c|}
\hline \multirow{2}{*}{ Organs } & \multicolumn{4}{|c|}{ Age (Weeks) } \\
\hline & 5 & 7 & 9 & 11 \\
\hline Body $(g)$ & $228 \pm 8(20)$ & $300 \pm 11(20)$ & $553 \pm 22(20)$ & $1221 \pm 42(20)$ \\
\hline Liver (g) & $4.43 \pm 0.19(20)$ & $6.4^{4} \pm 0.27(20)$ & $11.84 \pm 0.56(20)$ & $22.91 \pm 0.62(20)$ \\
\hline Thymus (mg) & $710 \pm 55(20)$ & $537 \pm 53(20)$ & $1395 \pm 115(19)$ & $1920 \pm 19(19)$ \\
\hline Bursa (mg) & $684 \pm 58(20)$ & $317 \pm 45(20)$ & $752 \pm 81(19)$ & $1340 \pm 65(20)$ \\
\hline Adrenals (mg) & $36.2 \pm 1.6(20)$ & $46.2 \pm 2.0(20)$ & $64.0 \pm 2.1(20)$ & $94.0 \div 4.0(20)$ \\
\hline Gonads (mg) & $51.9 \pm 3.8(20)$ & $54.3 \pm 4.8(20)$ & $94.1 \pm 7.5(19)$ & $198.0 \pm 11.0(20)$ \\
\hline
\end{tabular}


The age period that we observed is characterized by intensive growth : the final body weight of our chicks was about 6 times the initial one (table I). The development of various organs does not parallel the increase in body weight (fig. I) (1). Interesting evolutions are to be seen in the thymus and the bursa Fabricii : the relative weight of these organs oscillate, but has a general decreasing tendency. As far as the bursa is concerned, our data are in agreement with those given in the literature (PAYNE, I97I) : the maximal relative weight is reached before the age of 5 weeks. Concerning the thymus, various authors report much different findings : a slower increase than that of the bursa (KLIMA, I958), or a continuous increase until four months (PAYNE, I97I). In an other series of experiments, one of us (R. G., unpublished results) obtained also a different picture of the evolution of the thymus weight. This diversity of results must be put into connection with the great lability of the thymus, the development of which is largely depending on the conditions of rearing.

Fig. 1

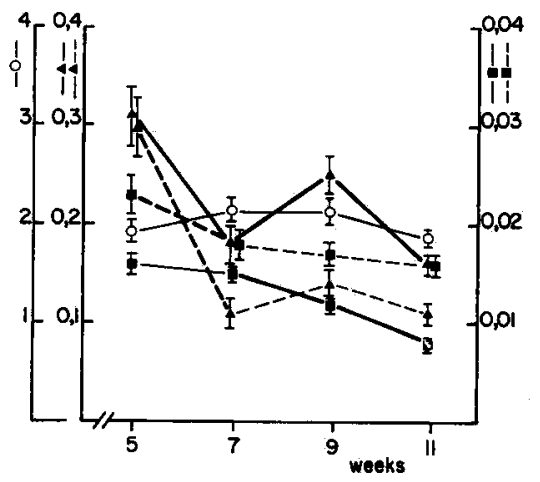

Fig. 2

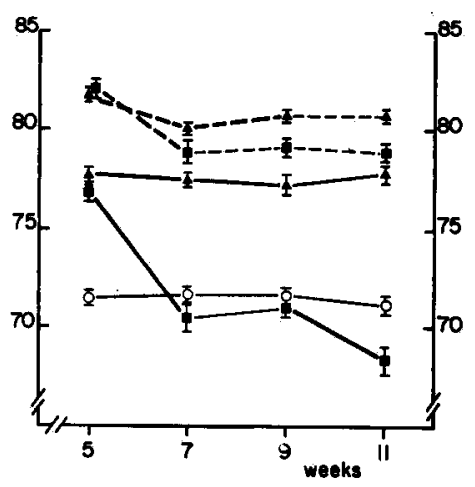

FIG. I. - Relative organ weights (percentages from the body weight)

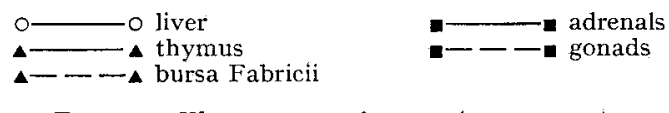

FIG. 2, - Water content of organs (percentages)

(Signs are the same as in figure $\mathrm{I}$ )

The marked decrease of the weight of both glands at the age of 5-7 weeks cannot be explained by the variation of the water content. Indeed, such a variation does occur in the case of the bursa (fig. 2), but it is, though significant, much too small to account for the loss in organ weight. In the sexual glands only, the decrease of the relative weight is rather completely accounted for by a loss of water (fig. I and 2).

Our results show a marked increase of the hematocrit value until the age of 7 weeks (fig. 3). This is not in agreement with the data of Freeman (I97 I $a$ ) concerning the definitive blood picture reached by 3 -week chicks. Later, a decrease of the hematocrit occurs, not paralleled by any change of the hemoglobin content of the blood. This signifies an increase of the hemoglobin concentration of the erythrocytes.

(1) In all figures, means are given, calculated after the elimination of aberrant individual values according to CHAUVENET's criterium. Corresponding standard errors are shown by vertical bars in the graphs. Statistical significance of the difference between adjacent values $(i . e$. significance of modifications occurring during a two weeks period) was calculated according to Student's i $\mathrm{t}$ " test, and $\mathrm{P}<0.05$ is indicated in the figures by thick lines. 
Fig. 3

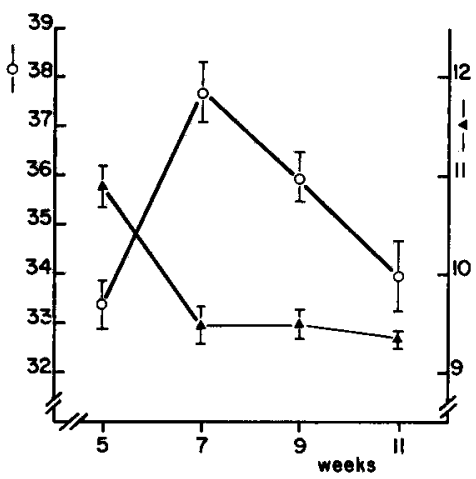

FIG. 3. - Erythrocytes

o hematocrit value, in percentages

4 hemoglobin concentration of the blood, grams per $100 \mathrm{~cm}^{3}$

FIG. 4. - Calcium and phosphate concentrations of the blood plasma $\longrightarrow \mathrm{Ca}$ concentration, $\mathrm{mg} / \mathrm{I} 00 \mathrm{~cm}^{3}$
$\mathrm{P} / \mathrm{Ca}$ ratio

The calcium and the phosphate concentrations of the blood plasma change in approximately the same manner (fig. 4). Thus, the $\mathrm{P} / \mathrm{Ca}$ ratio does not undergo very large variations, though these are statistically significant. Here also, the maximum is reached at 7 weeks.

Fig. 5

Fig. 6
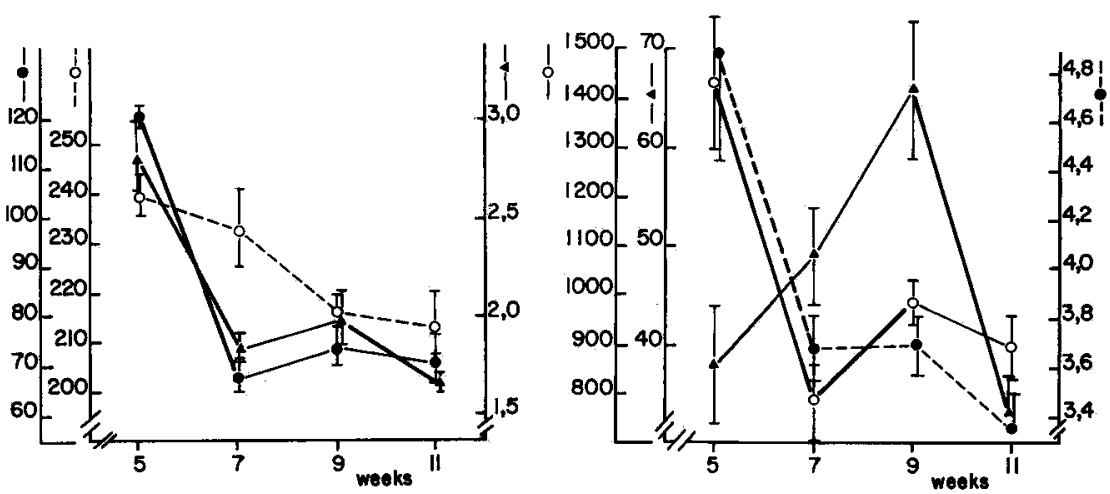

Fig. 5. - Fat, cholesterol, and ascorbic acid

- lipids in the liver, $\mathrm{mg} / \mathrm{g}$ (dry weight)

- - o cholesterol in the blood, $\mathrm{mg} / 100 \mathrm{~cm}^{3}$

$\Delta$ ascorbic acid in the adrenals, (mg/g (fresh weight)

FIG. 6. - Liver enzyme activities

glutamate-oxaloacetate aminotransferase,

- glutamate-pyruvate aminotransferase, both as milligrams pyruvic acid liberated per gram fresh tissue; succinate dehydrogenase activity, as microatoms oxygen consumed per minute and per gram fresh tissue. 
During the first interval ( 5 to 7 weeks of age) the fat reserve of the liver drastically falls down (fig. 5). This is paralleled by a decrease in blood cholesterol concentration (fig. 5), and by an incipient increase of the liver glycogen content (fig. 7). These modifications may indicate a switch of the main metabolic role from fats to carbohydrates. The slow but continuous decrease of cholesterolemia may be in connection with the maturation of the nervous system, which synthesyzes and liberates, during its development, large amounts of cholesterol (TchEN, 1960). Parallelly with the diminishing of the hepatic lipid store, the succinate dehydrogenase activity of the'liver also decreases (fig. 6), which is in agreement with the existing data on the gradual reducing of the metabolic rate (STURKIE, I965).

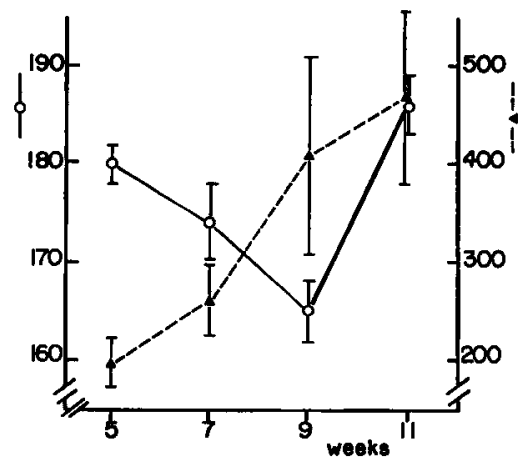

FIG. 7. - Carbohydrates

o- blood glucose concentration, $\mathrm{mg} / \mathrm{roo} \mathrm{cm}^{3}$

$\Delta-\ldots-\Delta$ liver glycogen, content, $\mathrm{mg} / \mathrm{IoO} \mathrm{g}$ (fresh weight)

A discrepancy appears in our results between the biphasic modification of the glycemia and the rather evenly increase of the hepatic glycogen reserve (fig. 7). It is likely that modifications take place in the hepatic and/or peripheral glucose utilization during the investigated ontogenetical period.

Summing up, our results indicate that large modifications occur in the metabolism of chicks by about 7 weeks of posteclosional life. Some of these modifications show a pronounced parallelism (see figs. 5, 6, 7). Though the functional significance is not always clear, a correlation in these cases is to be supposed. It is likely that we have to do with one of the "critical periods " of the ontogenetical development of the fowl.

Reçu pour publication en juillet 1975.

\section{ACKNOWLEDGEMENT}

This work was financially supported by the "Pasteur "Institute for Veterinary Research and Biopreparations, Bucharest. 


\section{RÉSUMÉ}

\section{MODIFICATIONS DE QUELQUES PARAMÈTRES PONDÉRAUX ET MÉTABOLIQUES CHEZ LE POULET ENTRE I ET 3 MOIS}

On a étudié des indices pondéraux et métaboliques au cours du développement de poulets Studler-Cornish âgés de 5 à I I semaines. Au cours de cette période le poids du corps augmente six fois. Le poids des organes ne varie pas toujours parallèlement à celui du corps; le poids relatif du thymus et celui de la bourse de Fabricius montrent une tendance à la diminution, très marquée entre 5 et 7 semaines. L'hématocrite augmente de 5 à 7 semaines, puis diminue. En rapprochant cette variation de celle de la concentration en hémoglobine on en déduit une augmentation du contenu des érythrocytes en pigment entre 7 et I I semaines. A 7 semaines on observe une forte diminution de la réserve hépatique en graisses, une baisse de la cholestérolémie et de la glycémie, ainsi que de l'activité de la SDH hépatique ; en même temps, le contenu hépatique en glycogène augmente. On en conclut que l'âge d'environ 7 semaines est une "période critique " dans la vie du poulet; il semble que cette "crise " comprend le passage du rôle principal dans le métabolisme énergétique des graisses aux glucides, ainsi que certaines modifications dans l'utilisation tissulaire du glucose.

\section{REFERENCES}

Asatiani S. V., I957. Biokhimicheskaja fotometrija, p. 3II-312.

Bolton T. B., I97I. The physiology of the nervous system. In : Bell D. J. and Freeman B. M. (Eds.), Physiology and biochemistry of the domestic fowl, vol. 2, p. 675-705, Academic Press, London and New York

Fauvert R., I96r-r962. Techniques modernes de laboratoire, $3^{\circ}$ éd., p. I 7r. Éd. Doin, Paris.

Freeman B. M., I97I $a$. The corpuscles and the physical characteristics of blood. In : BeLL D. J. and Freeman B. M. (Eds.), Physiology and biochemistry of the domestic fowl, vol. 2, p. $84 \mathrm{I}-852$, Academic Press, London and New York.

Freeman B. M., I97I $b$. Body temperature and thermoregulation. In : Bell D. J. and Freeman B. M. Eds., Physiology and biochemistry of the domestic fowl, vol. 2, p. III5-II5. Academic Press, London and New York.

Gilbert A. B., I97r. The ovary. In : Bell D. J. and Freeman B. M. (Eds.), Physiology and biochemistry of the domestic fowl, vol. 3, p. II63-1 208, Academic Press, London and New York.

Klima M., 1958. Beitrag zur Morphologie der Bursa Fabricii der Vögel. Sylvia, 15, I5I-I7o.

Kuznetsova L. A., Pertseva M. N., I974 a. Activity of phosphoglucomutase and phosphohexoisomerase in muscles of chicken embryos and chickens, in normal state and after adrenaline administration (In Russian). Ukr. biokhim. J, 46, 772-776.

Kuznetsova L. A., Pertseva M. N., I974 $b$. Effect of adrenaline and cyclic AMP on glycogen synthetase activity in skeletal muscles of developing fowl (In Russian). J. evol. Biokhim. Fiziol., 10, $440-445$.

LAKe P. E., I97I, The male in reproduction. In : Bell D. J. and Freeman B. M. (Eds.), Physiology and. biochemistry of the domestic fowl, vol. 3, p. I4I I-I447, Academic Press, London and New York.

Leibson L. G., Plisetskaya E. M., Bodareva V. M., I974. Effect of insulin on the glycogen synthetase activity in the muscles of chicken embryos and of chicks of various ages (In Russian). J. evol. Biokhim. Fiziol., 10, 433-439.

Montgomery R., 1957. The determination of glycogen. Arch. Biochem. Biophys., 67, 378-386.

Nelson N., I944. A photometric adaptation of the Somogyi method for the determination of glucose. J. biol. Chem., 153, 375-380.

Nvota J., Lamošová D., FÁberová A., I973. Critical periods in the development of chicks. Physiol. bohemoslov., 22, 337-343.

Payne L. N., I971. The lymphoid system. In : Bell D. J. and Freeman B. M. (Eds.), Physiology and biochemistry of the domestic fowl, vol. 2, p. 985-I037, Academic Press, London and New York.

Pertseva M. N., Zheludkova Z. P., Kuznetsova L. A., 1974. On the role of $3^{\prime}$, 5'-AMP and of calcium in the effect of adrenaline on the carbohydrate metabolism of chick muscles during the development (In Russian). J. evol. Biokhim. Fiziol., 10, 592-597.

Sturkie P. D., I965. Avian physiology. and edition. Comstock Publish. Assoc., Ithaca.

Tchen T. T., 1960. Metabolism of sterols. In : Greenberg D. M. (Ed.), Metabolic pathways, vol. I, p. 389-429, Academic Press, New York and London.

Tsinovy J V. I., 1967. Protein complexes of the blood in chicken embryos and chickens (In Russian). In : Fiziologija ptits/Physiology of the birds (In Russian), p. 3I-35, Valgus, Tallin. 